\title{
A nitrogén és a réz közötti kölcsönhatás vizsgálata szabadföldi kukorica kísérletben
}

\author{
KÁDÁR Imre és CSATHÓ Péter
}

MTA ATK Talajtani és Agrokémiai Intézet, Budapest

\section{Bevezetés}

A nitrogén és a réz elemek közötti kölcsönhatásokat KÁDÁR és SHALABY (1984, 1985) vizsgálta tenyészedény-kísérletekben meszes homok és vályog talajokon, árpa és köles jelzőnövénnyel. $\mathrm{A} \mathrm{CuSO}_{4}$ formában adott $\mathrm{Cu}$-terhelést mindkét talaj $\mathrm{KCl}+$ EDTA oldható $\mathrm{Cu}$-tartalma jól tükrözte. A növényi hozamokat a $\mathrm{Cu}$-trágyázás nem befolyásolta. A mintegy $10 \mathrm{mg} \cdot \mathrm{kg}^{-1} \mathrm{Cu}$-adaggal a tavaszi árpa gyökereinek Cu-tartalma vályogtalajon $10-15 \mathrm{mg} \cdot \mathrm{kg}^{-1}$, homoktalajon pedig $30-40 \mathrm{mg} \cdot \mathrm{kg}^{-1}$ értékkel nőtt meg. A földfeletti hajtás Cu-koncentrációja ugyanakkor nem módosult érdemben, a $\mathrm{Cu}$ növényen belüli transzportja gátolt volt. A N-böség bizonyos határig igazolhatóan növelte a $\mathrm{Cu}$ beépülését a gyökerekbe.

A továbbiakban rátérünk a $\mathrm{NxCu}$ közötti kölcsönhatásokat vizsgáló szabadföldi tartamkísérletünk bemutatására. A kísérlet 1988-2002 között folyt az MTA TAKI Nagyhörcsöki Kísérleti Telepén, vályog fizikai féleségű mészlepedékes csernozjom talajon. A növényváltás tavaszi árpa, búza, őszi árpa, kukorica, tritikále, burgonya, zab, rozs, négy éven át lucerna, repce, mák és napraforgó növényfajokat foglalta magába. A növények termésének meghatározásán túl rendszeresen mértük a növényi szervek és a kísérleti parcellák talajának elemösszetételét is.

Ismeretes, hogy a talaj tápelemkínálatának, illetve a növény tápláltsági állapotának megítélésére a kalászosok esetében a bokrosodáskori fiatal hajtás összetétele a leginkább alkalmas. Ekkor az elemtartalom nagy és széles tartományban változhat. Ezt követően a gyors szárazanyag-felhalmozás miatt gyors hígulás lép fel. LÁSZTITY (1985) pl. azt tapasztalta, hogy a tavaszi árpa bokrosodáskori elemtartalmát 100-nak véve a virágzásig a N 33, a P 44, a K 25, a Ca 48 és a Mg 55 \%-ra esett vissza.

Jelen munkánkban a N- és a Cu-kezelések hatását taglaljuk a kukorica fejlődésére, termésére, a növényi részek makro- és mikroelem tartalmára, valamint a fö- és mellékterméssel kivont elemek mennyiségére.

Postai cím: KÁDÁR IMRE, MTA Agrártudományi Kutatóközpont, Talajtani és Agrokémiai Intézet, 1022 Budapest, Herman Ottó út 15., Email: kadar@rissac.hu 
A szakirodalmi áttekintést, a termőhely talajviszonyait, valamint a kísérlet körülményeit előző közleményünkben ismertettük (KÁDÁR \& CSATHÓ, 2014).

A kukorica mütrágyázásával foglalkozó nagyszámú egyedi közlést nem tárgyaljuk. A hazai szerzők a kukoricát a nitrogénre és káliumra igényes, a foszforra kevésbé igényes termesztett növényünknek írják le (DEBRECZENI \& DEBRECZENI, 1994; GYŐRFFY \& BERZSENYI, 1994; NAGY, 2006; DeBreCZENI \& NÉMETH, 2009). Az 1960-2000 évek között publikált 65 kukorica N-trágyázási tartamkísérlet adatbázisában talált összefüggéseket és a kukorica N-hatásokat befolyásoló tényezőit a közelmúltban CSATHÓ (2003) foglalta össze.

\section{Anyag és módszer}

A NxCu kölcsönhatásokat vizsgáló kéttényezös kísérletet 1988 tavaszán állítottuk be az MTA TAKI Nagyhörcsöki Kísérleti Telepén. A kísérlet talaja löszön képződött meszes csernozjom, mely a kísérlet beállítása előtt 1988. március elején végzett talajvizsgálataink szerint mintegy $5 \% \mathrm{CaCO}_{3}$-ot és $3 \%$ humuszt tartalmazott a szántott rétegben.

A pH(KCl) 7,3; az AL- $\mathrm{P}_{2} \mathrm{O}_{5} 128 \mathrm{mg} \cdot \mathrm{kg}^{-1}$, az AL- $\mathrm{K}_{2} \mathrm{O} 243 \mathrm{mg} \cdot \mathrm{kg}^{-1}$, a $\mathrm{KCl}-\mathrm{Mg}$ 150-180 mg $\mathrm{kg}^{-1}$, az EDTA-Mn $127 \mathrm{mg} \cdot \mathrm{kg}^{-1}$, az EDTA-Cu 2-3 $\mathrm{mg} \cdot \mathrm{kg}^{-1}$ és az EDTA-Zn 1-2 mg $\mathrm{kg}^{-1}$ értékekkel jellemezhetők. A KCl-oldható $\mathrm{NH}_{4}-\mathrm{N}$ és a $\mathrm{NO}_{3}$ $\mathrm{N}$ tartalom a feltalajban 9, illetve $12 \mathrm{mg} \cdot \mathrm{kg}^{-1}$. A MÉM NAK (1979) által elfogadott módszerek és határértékek alapján ezek az adatok a talaj jó Ca-, Mg-, K-, Mn-, kielégítő $\mathrm{Cu}$-, közepes $\mathrm{N}$-, valamint gyenge $\mathrm{P}$ - és Zn-ellátottságáról tanúskodnak.

A talajvíz szintje 13-15 m mélyen helyezkedik el, a terület aszályérzékeny. Éghajlata az Alföldéhez hasonlóan szárazságra hajló, átlagos középhőmérséklete 11 ${ }^{\circ} \mathrm{C}$, éves átlagos csapadékösszege $576 \mathrm{~mm}$ (KÁDÁR \& CsATHÓ, 2014).

A kísérlet osztott parcellás (split-plot) elrendezésủ $4 \mathrm{Nx} 3 \mathrm{Cu}=12$ kezeléssel és három ismétléssel, összesen 36 parcellával. A parcellák mérete 4,9x15 =73,5 $\mathrm{m}^{2}$ volt. A vizsgált tényezők az alábbiak:

$$
\begin{aligned}
& \text { 1. tényezö (föparcellák): } \\
& \mathrm{N}_{0}=\text { kontroll } \\
& \mathrm{N}_{1}=100 \mathrm{~kg} \cdot \mathrm{ha}^{-1} \cdot \mathrm{é}^{-1} \mathrm{~N} \\
& \mathrm{~N}_{2}=200 \mathrm{~kg} \cdot \mathrm{ha}^{-1} \cdot \mathrm{é}^{-1} \mathrm{~N} \\
& \mathrm{~N}_{3}=300 \mathrm{~kg} \cdot \mathrm{ha}^{-1} \cdot \mathrm{év}^{-1} \mathrm{~N}
\end{aligned}
$$

$$
\begin{aligned}
& \text { 2. tényező (alparcellák): } \\
& \mathrm{Cu}_{0}=\mathrm{kontroll} \\
& \mathrm{Cu}_{1}=50 \mathrm{~kg} \cdot \mathrm{ha}^{-1} \mathrm{Cu} 1988 \text { tavaszán } \\
& \mathrm{Cu}_{2}=100 \mathrm{~kg} \cdot \mathrm{ha}^{-1} \mathrm{Cu} 1988 \text { tavaszán }
\end{aligned}
$$

Az alaptrágyázás évente $100 \mathrm{~kg} \mathrm{P}_{2} \mathrm{O}_{5} \cdot \mathrm{ha}^{-1}$ és $100 \mathrm{~kg} \mathrm{~K} 2 \mathrm{O} \cdot \mathrm{ha}^{-1}$ adagot jelentett szuperfoszfát és kálisó formájában. A N-t 25\%-os pétisó $\left(\mathrm{NH}_{4} \mathrm{NO}_{3}+\mathrm{CaCO}_{3}\right)$, a $\mathrm{Cu}$ trágyát 25,5\%-os $\mathrm{CuSO}_{4} \times 5 \mathrm{H}_{2} \mathrm{O}$ formában alkalmaztuk. A PK mütrágyákat és a $\mathrm{N}$ felét 1987 öszén az elővetemény lucerna törésére szórtuk ki, majd leszántottuk, míg a $\mathrm{N}$ másik felét és a $\mathrm{CuSO}_{4}$ trágyát 1988 tavaszán kevertük a talajba vetés elött.

A Pioneer 3732 hibridet április végén vetettük el 5-7 cm mélyre, $70 x 25 \mathrm{~cm}$ sor $\mathrm{x}$ tőtávra, $20 \mathrm{~kg} \cdot \mathrm{ha}^{-1}$ vetőmaggal. 
A 4-6 leveles korban 20-20 gyökeres növényt, virágzás elején 20-20 db csőalatti levelet, majd betakarítás elött 20-20 db csöves mintakévét szedtünk parcellánként. Ekkor határoztuk meg az összes termő és meddő tövek számát is, szintén parcellánként. Mértük a minták friss és légszáraz tömegét, majd az analízisre előkészítettük. Az 1000-szem számlálás 4x50 szem mérésén alapult kezelésenként. A betakaritás október 17-én történt parcellakombájnnal. A szár- és a csutkatermés tömegét, illetve a morzsolási arányt a mintakévék feldolgozása nyomán számoltuk.

A növényállományt parcellánként 1-5 skálán bonitáltuk 4-6 leveles fejlettségnél, virágzás és betakarítás idején. A betakarítást követően talajmintákat vettünk a szántott rétegből, parcellánként 20-20 lefúrásból képezve átlagmintákat. A növényeket makro- és mikroelemekre vizsgáltuk. A talajmintákban meghatároztuk a $\mathrm{KCl}+$ EDTA oldható Cu-tartalmat, valamint a KCl-kicserélhetö $\mathrm{NH}_{4}-\mathrm{N}$ és $\mathrm{NO}_{3}-\mathrm{N}$ tartalmat a MÉM NAK (1978) által ismertetett eljárásokkal.

A főbb agrotechnikai műveletekről és a módszertani/mintavételi eljárásokról az 1. táblázat nyújt áttekintést.

\section{1. táblázat}

Agrotechnikai müveletek és megfigyelések a kukoricakísérletben 1991-ben (Mészlepedékes csernozjom vályogtalaj, Nagyhörcsök, Mezőföld)

\begin{tabular}{|c|c|c|}
\hline $\begin{array}{c}(1) \\
\text { Mủveletek megnevezése }\end{array}$ & $\begin{array}{c}\text { (2) } \\
\text { Időpont }\end{array}$ & $\begin{array}{l}\text { (3) } \\
\text { Egyéb megjegyzések }\end{array}$ \\
\hline Öszi mütrágyázás (N, P, K) & 1990.09.09. & Parcellánként kézzel \\
\hline Egyirányú szántás & 1990.09.09. & MTZ-50+Lajta eke \\
\hline Fogasolás & 1991.03 .27 & MTZ-50+fogas \\
\hline Tavaszi N-mütrágyázás & 1991.04 .15 & Parcellánként kézzel \\
\hline Kombinátorozás & 1991.04.15. & MTZ-50+kombinátor \\
\hline Vetés (Hibrid: Pi 3732) & 1991.04.30. & MTZ-50+SPC-6 vetőgép \\
\hline Sorközmüvelés, tőszámbeállítás & 1991.05.20. & Parcellánként kézzel \\
\hline Növénymintavétel (4-6 leveles) & 1991.07.02. & Parcellánként 20 gyökeres növény \\
\hline Bonitálás állományra & 1991.07.02. & Parcellánként 1-5 skálán \\
\hline Bonitálás címerhányáskor & 1991.08 .04$. & Parcellánként 1-5 skálán \\
\hline Levélmintavétel & 1991.08.06. & Parcellánként $20 \mathrm{db}$ csőalatti levél \\
\hline Bonitálás aratás előtt & 1991.10 .17$. & Parcellánként 1-5 skálán \\
\hline Mintakéve szedése & 1991.10 .17$. & Parcellánként 20 tő csövesen \\
\hline Betakarítás & 1991.10.17. & Parcellánként $13 \times 2,8=36,4 \mathrm{~m}^{2}$ \\
\hline Ezerszem számlálása & 1991.11.19. & Parcellánként $4 \times 500$ szem \\
\hline Mintakévék feldolgozása & 1991.11.25. & Parcellánkénti cséplés, mérések \\
\hline Minták szárítása, őrlése & 1991.12.10. & Parcellánkénti előkészítés \\
\hline
\end{tabular}

Megjegyzés: Vetés 5-7 cm mélyre, $70 \times 25 \mathrm{~cm}$ sor x tőtávra $20 \mathrm{~kg} \cdot \mathrm{ha}^{-1}$ vetömagnormával 


\section{Kísérleti eredmények}

A N-trágyázás 4-6 leveles korban és címerhányás/virágzás elején egyaránt mérsékelte az állomány fejlettségét, magasságát.

Betakarításkor ez a negatív hatás nem volt igazolható a bonitálás eredményeiben. Megállapítottuk azonban, hogy a N-túlsúly, azaz az agronómiailag indokoltat jelentősen meghaladó $\mathrm{N}$-adagok csökkentették az összes és ezen belül a termö tövek számát.

A szemszám/termő tő $400 \mathrm{db}$, a szemtömeg/cső $110 \mathrm{~g}$, az 1000-szem tömege 278 g, illetve a morzsolási arány $88 \%$ volt átlagosan. A négyzetméterenkénti szemszám 2 700, azaz mintegy 27 millió szem képződött hektáronként (2. táblázat).

\section{2. táblázat}

N-kezelések hatása a kukorica fejlődésére és az aratáskori tőszám alakulására 1991-ben (Mészlepedékes csernozjom vályogtalaj, Nagyhörcsök, Mezőföld)

\begin{tabular}{|c|c|c|c|c|c|c|}
\hline$\stackrel{(1)}{\mathrm{N} \text {-adagok }}$ & \multicolumn{3}{|c|}{$\begin{array}{c}\text { Bonitálás }(1=\text { gyengén, } \\
5=\text { jól fejlett })\end{array}$} & \multicolumn{3}{|c|}{ Tőszámlálás aratáskor } \\
\hline \multirow{2}{*}{$\mathrm{kg} \cdot \mathrm{ha}^{-1} \cdot \mathrm{é}^{-1}$} & \multirow{2}{*}{07.02 . } & \multirow{2}{*}{08.04} & \multirow{2}{*}{10.17 . } & $\begin{array}{c}(4) \\
\text { Termő }\end{array}$ & $\begin{array}{c}(5) \\
\text { Meddő }\end{array}$ & $\begin{array}{c}\text { (6) } \\
\text { Összes }\end{array}$ \\
\hline & & & & \multicolumn{3}{|c|}{$1000 \mathrm{db} \cdot \mathrm{ha}^{-1}$} \\
\hline 0 & 3,0 & 3,9 & 4,1 & 71 & 9 & 80 \\
\hline 100 & 2,3 & 3,1 & 4,3 & 66 & 11 & 77 \\
\hline 200 & 2,7 & 3,4 & 4,4 & 69 & 9 & 78 \\
\hline 300 & 2,4 & 3,2 & 4,1 & 65 & 10 & 75 \\
\hline Átlag & 2,6 & 3,4 & 4,3 & 68 & 10 & 77 \\
\hline $\mathrm{SzD}_{5 \%}$ & 0,5 & 0,5 & 0,4 & 4 & 3 & 5 \\
\hline
\end{tabular}

Megjegyzés: Szemszám/termő tő átlagosan $399 \mathrm{db}$, szemtömeg/cső $111 \mathrm{~g}$, szemszám db $\cdot \mathrm{m}^{-2}$ $2700 \mathrm{db}, 1000$-szemtömeg $278 \mathrm{~g}$, morzsolási arány 88\%, effektivitás 67\%, kezelésektől függetlenül

A NxCu kezelések hatását a légszáraz kukoricára a 3. táblázatban foglaltuk öszsze. A fiatal hajtás, a betakarításkori szár- és szemtömegét a N-túlsúly mérsékelte, míg a Cu-trágyázás esetenként növelte. A pozitív Cu-hatások alapvetően a $\mathrm{N}$ kontrollkezelésekben figyelhetők meg, tehát a N-túltrágyázás okozta depressziót a $\mathrm{Cu}$-adagok érdemben nem ellensúlyozták.

Megemlítjük, hogy a légszáraz 4-6 leveles gyökér tömegét a N-túlsúly a Nkontrollon mért $24 \mathrm{~g} / 20$ db értékről igazolhatóan $19 \mathrm{~g} / 20 \mathrm{db}$-ra mérsékelte. A csutka átlagosan $1 \mathrm{t} \cdot \mathrm{ha}^{-1}$ - a szemtermés $12 \%$-a - volt, a morzsolási arány $88 \%$-nak adódott.

A 4-6 leveles hajtás, illetve a címerhányáskori levél N-tartalma nem nőtt a Nadagokkal. A kukorica N-hiányával már nem kell számolni amennyiben a hajtás és a levél 3,5\%, illetve 2,5\% körüli N-tartalom értéket ér el (BERGMANN, 1992). 


\section{3. táblázat}

A N x Cu kezelések hatása a légszáraz termésekre a kukorica különböző fenológiai fázisaiban,1991-ben (Mészlepedékes csernozjom vályogtalaj, Nagyhörcsök, Mezőföld)

\begin{tabular}{|c|c|c|c|c|c|c|}
\hline \multirow{2}{*}{$\stackrel{(1)}{\mathrm{Cu}-\mathrm{adag}}$} & & & ázás & & \multirow{3}{*}{ Átlag } & \multirow{3}{*}{$\begin{array}{c}(4) \\
\mathrm{SzD}_{5 \%}\end{array}$} \\
\hline & 0 & 100 & 200 & 300 & & \\
\hline $\mathrm{kg} \cdot \mathrm{ha}^{-1}$ & \multicolumn{4}{|c|}{$\mathrm{kg} \mathrm{N} \cdot \mathrm{ha}^{-1} \cdot \mathrm{év}^{-1}$} & & \\
\hline \multicolumn{7}{|c|}{ A. Légszáraz 4-6 leveles hajtás, g (20 db) } \\
\hline 0 & 75 & 70 & 66 & 71 & 70 & \\
\hline 50 & 82 & 68 & 90 & 71 & 78 & 14,0 \\
\hline 100 & 103 & 70 & 73 & 69 & 79 & \\
\hline Átlag & 86 & 69 & 77 & 70 & 76 & 8,0 \\
\hline $\mathrm{SzD}_{5 \%}$ & \multicolumn{4}{|c|}{12} & 6 & \\
\hline \multicolumn{7}{|c|}{ B. Légszáraz 4-6 leveles gyökér, g (20 db) } \\
\hline Átlag & 24 & 20 & 21 & 19 & 21 & 2,0 \\
\hline \multicolumn{7}{|c|}{ C. Légszáraz szár, $t \cdot h a^{-1}$} \\
\hline 0 & 4,8 & 4,2 & 4,0 & 4,2 & 4,3 & \\
\hline 50 & 4,6 & 4,5 & 4,0 & 4,0 & 4,3 & 1,0 \\
\hline 100 & 5,9 & 5,2 & 4,6 & 4,0 & 4,9 & \\
\hline Átlag & 5,1 & 4,6 & 4,2 & 4,1 & 4,5 & 0,5 \\
\hline $\mathrm{SzD}_{5 \%}$ & \multicolumn{4}{|c|}{0,8} & 0,4 & \\
\hline \multicolumn{7}{|c|}{ D. Légszáraz szem, $t \cdot h a^{-1}$} \\
\hline 0 & 7,4 & 6,8 & 7,0 & 7,0 & 7,0 & \\
\hline 50 & 7,6 & 7,6 & 8,4 & 7,7 & 7,8 & 1,0 \\
\hline 100 & 8,6 & 7,5 & 7,4 & 7,2 & 7,7 & \\
\hline Átlag & 7,8 & 7,3 & 7,6 & 7,3 & 7,5 & 0,5 \\
\hline \multicolumn{7}{|c|}{0,8} \\
\hline \multicolumn{7}{|c|}{ E. Légszáraz szár + csutka + szem, $t \cdot h a^{-1}$} \\
\hline 0 & 13,3 & 12,0 & 12,0 & 12,2 & 12,3 & \\
\hline 50 & 13,3 & 13,2 & 13,5 & 12,8 & 13,2 & 1,8 \\
\hline 100 & 15,7 & 13,7 & 13,0 & 12,2 & 13,6 & \\
\hline Átlag & 14,1 & 13,0 & 12,8 & 12,4 & 13,0 & 0,9 \\
\hline $\mathrm{SzD}_{5 \%}$ & \multicolumn{4}{|c|}{1,6} & 0,8 & \\
\hline
\end{tabular}

Megjegyzés: Csutka átlagosan $1 \mathrm{t} \cdot \mathrm{ha}^{-1}$, a morzsolási arány $88 \%$

Kísérletünkben már a N-kontroll parcellákon is kielégítő volt a N-ellátottság, a $\mathrm{N}$-túltrágyázás pedig nem vezetett a $\mathrm{N}$ luxusfelvételéhez. Ugyanezeken a parcellákon a gyökér N-akkumulációja igazolható. Az aratáskori szártermésben a Nkínálattal emelkedett a N-, K-, Ca-tartalom, míg a P mennyisége (\%) tendenciájában mérséklödött (4. táblázat). 
4. táblázat

A N-trágyázás hatása a kukorica elemtartalmára 1991-ben* (Mészlepedékes csernozjom vályogtalaj, Nagyhörcsök, Mezőföld)

\begin{tabular}{|c|c|c|c|c|c|c|c|c|c|}
\hline \multirow{2}{*}{$\begin{array}{c}(1) \\
\mathrm{N}-\text {-adagok }\end{array}$} & $\begin{array}{c}(2) \\
\text { Hajtás }\end{array}$ & $\begin{array}{c}(3) \\
\text { Gyökér }\end{array}$ & $\begin{array}{c}(4) \\
\text { Levél }\end{array}$ & \multicolumn{2}{|c|}{$\begin{array}{c}\text { (5) } \\
\text { Levél }\end{array}$} & \multicolumn{5}{c|}{ Aratáskori szártermés } \\
\cline { 2 - 10 } & $\mathrm{N}$ & $\mathrm{N}$ & $\mathrm{N}$ & $\mathrm{Na}$ & $\mathrm{Zn}$ & $\mathrm{N}$ & $\mathrm{K}$ & $\mathrm{Ca}$ & $\mathrm{P}$ \\
\hline $\mathrm{kg} \cdot \mathrm{ha}^{-1} \mathrm{év}^{-1}$ & \multicolumn{4}{|c|}{$\%$} & \multicolumn{3}{|c|}{$\mathrm{mg} \cdot \mathrm{kg}^{-1}$} & \multicolumn{4}{|c|}{$\%$} \\
\hline 0 & 3,26 & 1,58 & 2,75 & 90 & 14 & 0,63 & 1,05 & 0,30 & 0,10 \\
100 & 3,51 & 1,70 & 2,71 & 151 & 14 & 0,98 & 1,22 & 0,32 & 0,09 \\
200 & 3,33 & 1,80 & 2,91 & 165 & 15 & 0,86 & 1,18 & 0,34 & 0,08 \\
300 & 3,36 & 1,95 & 2,77 & 151 & 17 & 0,86 & 1,40 & 0,36 & 0,08 \\
a) Átlag & 3,37 & 1,76 & 2,78 & 139 & 15 & 0,83 & 1,21 & 0,33 & 0,09 \\
b) SzD & 0,30 & 0,22 & 0,16 & 44 & 2 & 0,10 & 0,20 & 0,04 & 0,02 \\
\hline
\end{tabular}

Megjegyzés: *Hajtás és gyökér 4-6 leveles korban; Levél a virágzás elején

A Cu-trágyázás hatását vizsgálva megállapítható, hogy a Cu-kínálattal a tövenkénti szemszám, illetve a csövenkénti szemsúly emelkedett. Az 1000-szem tömegre a Cu-kezelések nem hatottak, mely a kezelésektől függetlenül átlagosan 278 g-ot tett ki. A növényi szervek Cu-tartalmát a $\mathrm{Cu}$-trágyázás eltérően befolyásolta (5. táblázat).

A szemtermés Cu-tartalma nem módosult, míg a földfeletti vegetatív növényi részek Cu-tartalma átlagosan 1/3-ával nőtt, a gyökér Cu-készlete pedig 2,5szeresére dúsult. A Cu növényen belüli vertikális transzportja tehát gátolt volt. Hasonló eredményre jutottunk ugyanezen a mészlepedékes csernozjom vályog talajon korábban a nehézfém-terhelési kísérletünkben, ahol a $\mathrm{CuSO}_{4}$ formában maximálisan $810 \mathrm{~kg} \cdot \mathrm{ha}^{-1} \mathrm{Cu}$-adagot alkalmaztunk. A földfeletti növényi szervekben, a kukorica fiatal hajtásában, virágzáskori levelében, a szárban vagy a szemtermésben érdemi Cu-dúsulást nem tapasztaltunk (KÁDÁR et al., 2000).

\section{5. táblázat}

A Cu-trágyázás hatása a kukorica egyes terméselemeire és a növényi szervek Cu-tartalmára (Mészlepedékes csernozjom vályogtalaj, Nagyhörcsök, Mezőföld)

\begin{tabular}{|c|c|c|c|c|c|c|c|}
\hline \multirow{3}{*}{$\begin{array}{c}\text { (1) } \\
\text { Cu-adag } \\
\mathrm{kg} \cdot \mathrm{ha}^{-1}\end{array}$} & \multirow{2}{*}{\multicolumn{3}{|c|}{$\begin{array}{c}(2) \\
\text { Terméselemek aratáskor } \\
(4) \\
\text { Szem }\end{array}$}} & \multicolumn{4}{|c|}{$\begin{array}{c}\text { (3) } \\
\text { Cu-tartalom }\end{array}$} \\
\hline & & & & $\begin{array}{c}\text { (5) } \\
\text { Hajtás }\end{array}$ & $\begin{array}{c}\text { (6) } \\
\text { Gyökér }\end{array}$ & $\begin{array}{c}\text { (7) } \\
\text { Levél }\end{array}$ & $\begin{array}{c}(8) \\
\text { Szár }\end{array}$ \\
\hline & $\mathrm{db} \cdot \mathrm{ton}^{\prime-1}$ & $\mathrm{~g} \cdot \operatorname{csö}^{-1}$ & $\mathrm{db} \cdot \mathrm{m}^{-2}$ & \multicolumn{4}{|c|}{$\mathrm{mg} \cdot \mathrm{kg}^{-1}$} \\
\hline 0 & 384 & 106 & 2552 & 17 & 14 & 14 & 7 \\
\hline 50 & 409 & 114 & 2794 & 22 & 26 & 18 & 9 \\
\hline 100 & 403 & 112 & 2759 & 22 & 35 & 18 & 10 \\
\hline a) Átlag & 399 & 111 & 2702 & 20 & 25 & 17 & 9 \\
\hline b) $\mathrm{SzD}_{5 \%}$ & 10 & 6 & 218 & 3 & 5 & 3 & 2 \\
\hline
\end{tabular}

Megjegyzés: 1000-szem tömege $278 \mathrm{~g}$ átlagosan 
Az irodalmi adatok és saját vizsgálataink szerint a kukorica állománya diagnosztikai szempontból tápanyagokkal kielégítően ellátott, amennyiben a csővel szemközti levelek elemtartalma virágzás kezdetén az alábbi határok közötti: N: 2,53,5\%; P: 0,25-0,35\%; K: 1,5-2,5\%; Ca: 0,25-0,80\%; Mg: 0,2-0,6\%; Fe: 50-250, Mn: 20-200, Zn: 25-100, B: 5-40, Cu: 5-20 mg· $\mathrm{kg}^{-1}$ szárazanyag.

A kiegyensúlyozott tápláltági állapotot tükröző optimális elemarányok iránymutató jelleggel az alábbiak: N/P: 8-12; K/P: 6-9; K/Ca: 3-6; K/Mg: 4-8; Mn/Zn: 18; P/Fe: 20-100; P/Mn: 20-120; P/Zn: 50-150; P/Cu: 200-500; K/B: 60-3000 (KÁDÁr, 2006).

\section{6. táblázat}

A kukorica átlagos összetétele 1991-ben

(Mészlepedékes csernozjom vályogtalaj, Nagyhörcsök, Mezőföld)

\begin{tabular}{|c|c|c|c|c|c|c|}
\hline \multirow{2}{*}{$\begin{array}{l}\text { (1) } \\
\text { Elem } \\
\text { jele }\end{array}$} & \multirow{2}{*}{$\begin{array}{l}\text { (2) } \\
\text { Mértékegység }\end{array}$} & $\begin{array}{c}\text { (3) } \\
\text { Hajtás }\end{array}$ & $\begin{array}{c}(4) \\
\text { Gyökér }\end{array}$ & \multirow{2}{*}{$\begin{array}{c}\text { (5) } \\
\text { Levél } \\
\text { (9) } \\
\text { Virágzáskor }\end{array}$} & $\begin{array}{c}(6) \\
\text { Szalma }\end{array}$ & $\begin{array}{c}(7) \\
\text { Szem }\end{array}$ \\
\hline & & \multicolumn{2}{|c|}{$\begin{array}{c}(8) \\
4-6 \text { leveles korban }\end{array}$} & & \multicolumn{2}{|c|}{$\begin{array}{c}(10) \\
\text { Aratáskor }\end{array}$} \\
\hline $\mathrm{N}$ & $\%$ & 3,37 & 1,76 & 2,78 & 0,83 & 1,28 \\
\hline K & $\%$ & 4,20 & 2,40 & 1,81 & 1,21 & 0,30 \\
\hline $\mathrm{Ca}$ & $\%$ & 0,63 & 0,65 & 0,58 & 0,33 & $<0,01$ \\
\hline $\mathrm{Mg}$ & $\%$ & 0,36 & 0,31 & 0,33 & 0,26 & 0,08 \\
\hline $\mathrm{P}$ & $\%$ & 0,35 & 0,18 & 0,32 & 0,09 & 0,24 \\
\hline $\mathrm{Fe}$ & $\mathrm{mg} \cdot \mathrm{kg}^{-1}$ & 617 & 2900 & 195 & 584 & 23 \\
\hline $\mathrm{Na}$ & $\mathrm{mg} \cdot \mathrm{kg}^{-1}$ & 193 & 518 & 139 & 150 & 26 \\
\hline $\mathrm{Mn}$ & $\mathrm{mg} \cdot \mathrm{kg}^{-1}$ & 138 & 127 & 110 & 81 & 5 \\
\hline $\mathrm{Zn}$ & $\mathrm{mg} \cdot \mathrm{kg}^{-1}$ & 19 & 52 & 15 & 10 & 10 \\
\hline $\mathrm{Cu}$ & $\mathrm{mg} \cdot \mathrm{kg}^{-1}$ & 20 & 25 & 16 & 9 & 1,2 \\
\hline
\end{tabular}

A 6. táblázat adatai szerint a címerhányás/virágzás idején a növények minden vizsgált elemben kielégítően ellátottak voltak - a Zn kivételével. A főbb számított átlagos elemarányok alapján is hasonló következtetésre jutunk: $\mathrm{N} / \mathrm{P}: 8,7$; K/P: 5,7; $\mathrm{K} / \mathrm{Ca}: 3,1 ; \mathrm{K} / \mathrm{Mg}$ : 5,5; Mn/Zn: 7,0; P/Fe: 16; P/Mn: 29; P/Cu: 188; P/Zn: 213. A Zn hiánya azonban limitáló tényezővé válhatott. Korábbi kísérleteink szerint, amennyiben a P/Zn aránya 200 fölé emelkedik, indukált Zn-hiány léphet fel és a kukorica termése csökkenhet. Ilyenkor a Zn-trágyázás hatékony lehet, $\mathrm{ZnSO}_{4}$ talajba juttatásával vagy Zn-hexamin permetezéssel a terméscsökkenés megszüntethető (GYÖRI \& MÁTZ, 1979; GYÖRI et al., 1996; KÁDÁR \& TURÁN 2002; CSATHÓ et al, 2002).

A 6.táblázat adataiból az is látható, hogy a fiatal hajtásban elsősorban a $\mathrm{N}$, a $\mathrm{K}$ és a $\mathrm{P}$, míg a gyökében a $\mathrm{Fe}$, a $\mathrm{Na}$, a $\mathrm{Zn}$ és a $\mathrm{Cu}$ akkumulálódik. A virágzás elejei levél összetételét tekintve átmenetet képez a 4-6 leveles hajtás és a betakarításkori leveles szár között a N, K, Ca, Mg, P, Mn, Zn, Cu elemtartalomban. A szemtermésben a $\mathrm{N}$ és $\mathrm{P}$ elemek dúsulnak, míg a kukorica átlagos összetétele alapján a $\mathrm{K}, \mathrm{Ca}$, $\mathrm{Mg}, \mathrm{Fe}, \mathrm{Na}, \mathrm{Mn}$ és $\mathrm{Cu}$ fóként a szárban raktározódott. 
A Ca a szemben átlagosan $36 \mathrm{mg} \cdot \mathrm{kg}^{-1} \mathrm{koncentrációban} \mathrm{fordult} \mathrm{elő,} \mathrm{tehát} \mathrm{valójá-}$ ban mennyisége alapján már mikroelemnek minősült.

Kombájnos betakarításkor a tábla talaja főként $\mathrm{N}$ és $\mathrm{P}$ elemekben szegényedhet, mert a szár leszántásával a $\mathrm{K}$, a $\mathrm{Ca}$, a $\mathrm{Mg}$ és a mikroelemek többsége visszakerül a talajba. Amint a 7. táblázatban látható, a $12 \mathrm{t} \cdot \mathrm{ha}^{-1}$ földfeletti légszáraz biomassza kereken $114 \mathrm{~kg} \mathrm{~N}, 77 \mathrm{~kg} \mathrm{~K}\left(92 \mathrm{~kg} \mathrm{~K}_{2} \mathrm{O}\right), 22 \mathrm{~kg} \mathrm{P}\left(50 \mathrm{~kg} \mathrm{P} \mathrm{O}_{5}\right), 15 \mathrm{~kg} \mathrm{Ca}$, és $18 \mathrm{~kg}$ Mg elemet épített be. A Fe közel 3 kg-ot, a felvett $\mathrm{Na}$ 870, a Mn 402, a Zn 120 és a $\mathrm{Cu} 44$ g-ot tett ki. Az 1 t szemtermés + a hozzátartozó melléktermék úgynevezett fajlagos elemtartalma $15 \mathrm{~kg} \mathrm{~N}, 10 \mathrm{~kg} \mathrm{~K}\left(12 \mathrm{~kg} \mathrm{~K}_{2} \mathrm{O}\right)$ és $3 \mathrm{~kg} \mathrm{P}\left(7 \mathrm{~kg} \mathrm{P}_{2} \mathrm{O}_{5}\right)$ mennyiségnek adódott. Adataink a szaktanácsadásban is felhasználhatók a tervezett kukoricatermés elemszükségletének becslésekor.

\section{7. táblázat}

A kukorica átlagos elemfelvétele betakarításkor 1991-ben (Mészlepedékes csernozjom vályogtalaj, Nagyhörcsök, Mezőföld)

\begin{tabular}{|c|c|c|c|c|c|}
\hline $\begin{array}{c}(1) \\
\text { Elem } \\
\text { jele }\end{array}$ & $\begin{array}{c}\left(\begin{array}{c}(2) \\
\text { Mérték- } \\
\text { egység }\end{array}\right. \\
\text { Szalma }\end{array}$ & $\begin{array}{c}(4) \\
\text { Szem }\end{array}$ & $\begin{array}{c}(5) \\
\text { Együtt }\end{array}$ & $\begin{array}{c}(6) \\
\text { Fajlagos } \\
\text { tartalom* }\end{array}$ \\
\hline $\mathrm{N}$ & $\mathrm{kg} \cdot \mathrm{ha}^{-1}$ & 37,4 & 77,1 & 114 & 15 \\
$\mathrm{~K}$ & $\mathrm{~kg} \cdot \mathrm{ha}^{-1}$ & 54,4 & 22,5 & 77 & 10 \\
$\mathrm{Ca}$ & $\mathrm{kg} \cdot \mathrm{ha}^{-1}$ & 14,8 & 0,3 & 152 & 2 \\
$\mathrm{Mg}$ & $\mathrm{kg} \cdot \mathrm{ha}^{-1}$ & 11,7 & 6,0 & 18 & 2 \\
$\mathrm{P}$ & $\mathrm{kg} \cdot \mathrm{ha}^{-1}$ & 4,0 & 18,0 & 22 & 3 \\
$\mathrm{Fe}$ & $\mathrm{g} \cdot \mathrm{ha}^{-1}$ & 2628 & 172 & 2800 & 373 \\
$\mathrm{Na}$ & $\mathrm{g} \cdot \mathrm{ha}^{-1}$ & 675 & 195 & 870 & 116 \\
$\mathrm{Mn}$ & $\mathrm{g} \cdot \mathrm{ha}^{-1}$ & 364 & 38 & 402 & 54 \\
$\mathrm{Zn}$ & $\mathrm{g} \cdot \mathrm{ha}^{-1}$ & 45 & 75 & 120 & 16 \\
$\mathrm{Cu}$ & $\mathrm{g} \cdot \mathrm{ha}^{-1}$ & 36 & 8 & 44 & 6 \\
\hline
\end{tabular}

Megjegyzés: *1 t szem + a hozzátartozó melléktermés elemtartalma; A szalma- és szemtermés 4,5 illetve $7,4 \mathrm{t} \cdot \mathrm{ha}^{-1}$, összesen $12,0 \mathrm{t} \cdot \mathrm{ha}^{-1}$

\section{Összefoglalás}

Mészlepedékes csernozjom vályogtalajon beállított szabadföldi kísérletben vizsgáltuk a NxCu elemek közötti kölcsönhatásokat 1991-ben kukoricával. A termőhely talaja a szántott rétegben 3\% humuszt, $5 \%$ körüli $\mathrm{CaCO}_{3}$-ot és $\mathrm{kb}$. $20 \%$ agyagot tartalmazott.

Az elemzések alapján a terület talaja jó Ca-, Mg-, $\mathrm{K}-$, Mn-, kielégítő $\mathrm{Cu}-$, közepes N-, valamint gyenge-közepes P- és Zn-ellátottságú volt. A talajvíz $13-15 \mathrm{~m}$ mélyen van, tehát a terület aszályérzékeny. A kísérletet $4 \mathrm{Nx} 3 \mathrm{Cu}=12$ kezelés $\times 3$ ismétlés $=36$ parcellával állítottuk be osztott parcellás (split-plot) elrendezéssel. 
A N 0, 100, 200, $300 \mathrm{~kg} \cdot \mathrm{ha}^{-1}$, a Cu 0,50, $100 \mathrm{~kg} \cdot \mathrm{ha}^{-1}$ adagokat jelentett Caammóniumnitrát, illetve $\mathrm{CuSO}_{4}$ formájában. Az árpilis, május és a július hónapokat aszály jellemezte.

Főbb eredményeink:

1. Az 1991. év első fele erősen csapadékhiányos volt, a N-trágyázás terméscsökkenést eredményezett. Igazolhatóan mérséklődött a termő tövek száma. Az 1000-szem tömeg $278 \mathrm{~g}$ maradt. A Cu-trágyázással igazolhatóan emelkedett az egy tơre eső szemek száma, illetve a csövenkénti szemtömeg. A szemtermés az $\mathrm{NxCu}$ kezelésekben 7,0 és $8,6 \mathrm{t} \cdot \mathrm{ha}^{-1}$ között változott.

2. A N-túlsúly, azaz az agronómiailag indokoltat jelentősen meghaladó $\mathrm{N}$ adagok hatására a 4-6 leveles korú növény gyökerének N\%-a, a virágzáselejei levelek N- és Zn-felvétele, valamint az aratáskori szár N-, K- és Ca-koncentrációja nőtt. A Cu-trágyázással a kontrollhoz viszonyítva a fiatal hajtás, a virágzás elejei levél és a szár Cu-tartalma átlagosan 1/3-ával emelkedett. A gyökér $\mathrm{Cu}$-készlete a $\mathrm{Cu}$ adagolással 2,5-szeresére nött. A Cu növényen belüli vertikális mozgása azonban gátolt volt.

3. A $12 \mathrm{t} \cdot \mathrm{ha}^{-1}$ (szem + szár) földfeletti biomasszába kereken $114 \mathrm{~kg} \mathrm{~N}, 77 \mathrm{~kg} \mathrm{~K}$ (92 $\left.\mathrm{kg} \mathrm{K}_{2} \mathrm{O}\right), 22 \mathrm{~kg} \mathrm{P}\left(50 \mathrm{~kg} \mathrm{P}_{2} \mathrm{O}_{5}\right), 15 \mathrm{~kg} \mathrm{Ca}$, és $18 \mathrm{~kg} \mathrm{Mg}$ épült be. Az $1 \mathrm{t} \mathrm{szem} \mathrm{+} \mathrm{a}$ hozzátartozó melléktermék fajlagos elemtartalma $15 \mathrm{~kg} \mathrm{~N}, 10 \mathrm{~kg} \mathrm{~K}\left(12 \mathrm{~kg} \mathrm{~K}{ }_{2} \mathrm{O}\right), 3$ $\mathrm{kg} \mathrm{P}\left(7 \mathrm{~kg} \mathrm{P}_{2} \mathrm{O}_{5}\right)$, illetve $3 \mathrm{~kg}$ körüli $\mathrm{CaO}$ és $\mathrm{MgO}$ mennyiségnek adódott.

Adataink a tervezett kukoricatermés elemszükségletének számításakor a szaktanácsadásban használhatók fel.

Kulcsszavak: NxCu kölcsönhatások, szabadföldi kísérlet, kukorica

\section{Irodalom}

Bergmann, W., 1992. Nutritional Disorders of Plants. G. Fischer Verlag. Jena, Stuttgart, New York.

CsATHÓ P., LÁsZTITY, B. \& NAGY, L., 2002. Zn-hexaminos levéltrágyázás a kukorica Pindukálta Zn-hiány leküzdésére. Gyakorlati Agrofórum. 13. (12) 20-21.

CsATHÓ P., 2003. Kukorica N-hatásokat befolyásoló tényezők vizsgálata az 1960-2000 között publikált hazai szabadföldi kísérletek adatbázisán. Agrokémia és Talajtan. 52. $169-184$.

DEBRECZENI B. \& DeBRECZENI B.-NÉ (szerk.), 1994. Trágyázási Kutatások 1960-1990. Akadémiai Kiadó. Budapest.

DeBRECZENI B.-NÉ \& NÉMETH T. (szerk.), 2009. Az Országos Mütrágyázási Tartamkísérletek (OMTK) kutatási eredményei (1967-2001). Akadémiai Kiadó. Budapest.

GYÖRFFY B. \& BERZSENYI Z., 1994. Növénytermesztési tényezők hatása a kukorica termésére tartamkísérletben. In: Trágyázási Kísérletek, 1960-1990. (Szerk.: DeBRECZENI B. \& DEBRECZENI K.) 311-312. Akadémiai Kiadó. Budapest. 
GYÖRI, D. \& MÁTZ, G., 1979. Changes in the zinc and triptifan contents of maize grains as a response to increasing rates of phosphorus fertilization. Acta Agron. Hung. 28. $158-167$.

GYÖRI, Z. RUZSÁNYI, L., JÁSZBERÉNYI, I. VÁGÓ, J. \& LOCH, J., 1996. The Effect of N and $\mathrm{P}$ application on the $\mathrm{Mn}, \mathrm{Cu}$, and $\mathrm{Zn}$ content of the winter wheat. In: Fertilizers and Environment, Development in Plant and Soil Science. (Ed.: RodrigueZ-Barrueco, C.) 66. 499-502. Kluwer Academic Public. DordrechtBoston-London.

KÁDÁR I., 2006. Növény-és talajvizsgálatok értelmezése mütrágyázási tartamkísérletben. Növénytermelés. 55. (1-2) 123-137.

KÁDÁR I. \& SHALABY M. H., 1984. A nitrogén- és réztrágyázás közötti kölcsönhatások vizsgálata meszes homoktalajon. Agrokémia és Talajtan. 33. 269-274.

KÁDÁR I. \& ShalABY M. H., 1985. N és Cu trágyázás hatása a talaj és a növény tápelemtartalmára. Növénytermelés. 34. (2) 119-126.

KÁDÁR I., RADICS L. \& BANA K.-NÉ, 2000. Mikroelem-terhelés hatása a kukoricaállományra karbonátos csernozjom talajon. Agrokémia és Talajtan. 49. 181-204.

KÁDÁR I. \& TURÁN T., 2002. P-Zn kölcsönhatás mészlepedékes csernozjom talajon kukorica monokultúrában. Agrokémia és Talajtan. 51. (3-4). 381-394.

KÁDÁR I. \& CSATHÓ P., 2014. A nitrogén és réz közötti kölcsönhatások vizsgálata öszi búzában. Növénytermelés. 63. (2) 27-44.

LÁSZTITY B., 1985. A mütrágyázás hatása a tavaszi árpa szárazanyag-felhalmozására, tápelemtartalmára és arányaira. Növénytermelés. 34. 417-425.

MÉM NAK, 1978. A TVG tápanyagvizsgáló laboratórium módszerfüzete. MÉM Növényvédelmi és Agrokémiai Központ. Budapest.

MÉM NAK, 1979. Mütrágyázási irányelvek és üzemi számítási módszer. MÉM Növényvédelmi és Agrokémiai Központ. Budapest.

NAGY, J., 2006. Maize Production. Akadémiai Kiadó. Budapest.

Érkezett: 2015. október 17. 


\title{
Analysis of interactions between $\mathrm{N}$ and $\mathrm{C}$ fertilization in a field experiment on maize
}

\author{
I. KÁDÁR and P. CSATHÓ
}

Institute for Soil Science and Agricultural Chemistry, Centre for Agricultural Research, Hungarian Academy of Sciences, Budapest

\begin{abstract}
Summary
Interactions between the elements $\mathrm{N}$ and $\mathrm{C}$ were investigated in a field experiment on maize, set up on chernozem loam soil with lime deposits in 1991. The ploughed layer contained $3 \%$ humus, around $5 \% \mathrm{CaCO}_{3}$ and around $20 \%$ clay. Soil analysis revealed that the soil had good supplies of $\mathrm{Ca}, \mathrm{Mg}, \mathrm{K}$ and $\mathrm{Mn}$, satisfactory supplies of $\mathrm{Cu}$, a moderate quantity of $\mathrm{N}$ and a poor to medium level of $\mathrm{P}$ and $\mathrm{Zn}$. The groundwater was located at a depth of 13-15 m and the area was prone to drought. The experiment involved $4 \mathrm{~N} \times 3 \mathrm{Cu}=12$ treatments in 3 replications, giving a total of 36 plots arranged in a split-plot design. Nitrogen was supplied in the form of calcium ammonium nitrate at rates of $0,100,200$ and $300 \mathrm{~kg} \cdot \mathrm{ha}^{-1}$ and copper as $\mathrm{CuSO}_{4}$ at rates of 0,50 and 100 $\mathrm{kg} \cdot \mathrm{ha}^{-1}$. April, May and July were very dry.

The main results were as follows:

1. There was very little rainfall in the first half of 1991 , so $\mathrm{N}$ fertilization led to yield losses. There was a significant reduction in the number of fertile plants, and the 1000kernel weight was only $278 \mathrm{~g}$. Cu fertilisation resulted in a significant rise in the number of kernels per plant and in the grain weight per year. The grain yield ranged from $7.0-8.6 \mathrm{t} \cdot \mathrm{ha}^{-1}$ as a function of the $\mathrm{N} \times \mathrm{Cu}$ treatments.

2. In response to excessive $\mathrm{N}$ supplies, i.e. $\mathrm{N}$ rates substantially higher than the agronomically justifiable level, there was an increase in the $\mathrm{N} \%$ in the roots of plants in the 4-6-leaf stage, in the $\mathrm{N}$ and $\mathrm{Zn}$ uptake of the leaves at the beginning of flowering, and in the $\mathrm{N}, \mathrm{K}$ and $\mathrm{Ca}$ concentrations of the stalks at harvest. On average, the $\mathrm{Cu}$ contents in the young shoots, in leaves at the beginning of flowering and in the stalks were $1 / 3$ higher after $\mathrm{Cu}$ fertilisation, which was significantly higher than the control. The $\mathrm{Cu}$ concentration in the roots, however, exhibited a $2.5 \times$ increase after $\mathrm{Cu}$ application, indicating that the vertical movement of $\mathrm{Cu}$ within the plant was inhibited.

3. A total of around $114 \mathrm{~kg} \mathrm{~N}, 77 \mathrm{~kg} \mathrm{~K}\left(92 \mathrm{~kg} \mathrm{~K}_{2} \mathrm{O}\right), 22 \mathrm{~kg} \mathrm{P}\left(50 \mathrm{~kg} \mathrm{P}_{2} \mathrm{O}_{5}\right), 15 \mathrm{~kg} \mathrm{Ca}$ and $18 \mathrm{~kg} \mathrm{Mg}$ was incorporated into the $12 \mathrm{t} \cdot \mathrm{ha}^{-1}$ aboveground biomass (kernels + stalks). The specific element content of $1 \mathrm{t}$ grain + the corresponding by-products was $15 \mathrm{~kg} \mathrm{~N}, 10 \mathrm{~kg} \mathrm{~K}(12 \mathrm{~kg} \mathrm{~K} 2 \mathrm{O}), 3 \mathrm{~kg} \mathrm{P}\left(7 \mathrm{~kg} \mathrm{P}_{2} \mathrm{O}_{5}\right)$ and around $3 \mathrm{~kg}$ each of $\mathrm{CaO}$ and $\mathrm{MgO}$. These findings could provide guidelines for the extension service when calculating the element requirements of the planned maize yield.

Table 1. Agronomic operations and observations in the maize experiment in 1991 (chernozem loam soil with lime deposits, Nagyhörcsök, Mezőföld). (1) Operations and observations. (2) Date. (3) Methodological guidelines. Note: Sowing at a depth of 5-7 $\mathrm{cm}$ with $20 \mathrm{~kg} \cdot \mathrm{ha}^{-1}$ seed and a row and plant spacing of $70 \times 25 \mathrm{~cm}$.
\end{abstract}


Table 2. Effect of $\mathrm{N}$ treatments on the development of maize and the plant density at harvest in 1991 (chernozem loam soil with lime deposits, Nagyhörcsök, Mezőföld). (1) $\mathrm{N}$ rates, $\mathrm{kg} \cdot \mathrm{ha}^{-1} \cdot \mathrm{év}^{-1}$ (2) Scoring (1 = poorly developed, $5=$ well-developed). (3) Plant density at harvest. (4) Fertile, db $h^{-1}$ (5) Barren, db $\cdot \mathrm{ha}^{-1}$ (4) Total, db $\cdot \mathrm{ha}^{-1}$. a) Mean, b) LSD $_{5 \%}$. Note: Mean kernel No./plant 399, grain mass/ear $111 \mathrm{~g}$, kernel No./m² 2700, thousand-kernel weight $278 \mathrm{~g}$, shelling percentage $88 \%$, effectivity $67 \%$ irrespective of the treatments.

Table 3. Effect of $\mathrm{N} \times \mathrm{Cu}$ treatments on the air-dry yield of maize in various phenological phases, 1991 (chernozem loam soil with lime deposits, Nagyhörcsök, Mezőföld). (1) $\mathrm{Cu}$ rate, $\mathrm{kg} \cdot \mathrm{ha}^{-1}$. (2) $\mathrm{N}$ fertilisation, $\mathrm{kg} \mathrm{N} \cdot \mathrm{ha}^{-1} \cdot \mathrm{év}^{-1}$. (3) Mean. (4) $\mathrm{LSD}_{5 \%}$. A. Air-dry 4-6-leaf shoots, g. B. Air-dry roots of plants in the 4-6-leaf stage, g. C. Airdry stalks, $\mathrm{t} \cdot \mathrm{ha}^{-1}$. D. Air-dry kernels, $\mathrm{t} \cdot \mathrm{ha}^{-1}$. E. Air-dry stalks + cobs + kernels, $\mathrm{t} \cdot \mathrm{ha}^{-1}$. Note: Cobs averaged $1 \mathrm{t} \cdot \mathrm{ha}^{-1}$, shelling ratio $88 \%$.

Table 4. Effect of $\mathrm{N}$ fertilisation on the element content of maize in 1991 (chernozem loam soil with lime deposits, Nagyhörcsök, Mezöföld). (1) N rates, $\mathrm{kg} \cdot \mathrm{ha}^{-1} \mathrm{év}^{-1}$. (2) Shoots N, \%. (3) Roots N, \%. (4) Leaf N, \%. (5) Leaf element content, $\mathrm{mg} \cdot \mathrm{kg}^{-1}$ (6) Element content of the stalks at harvest, \%. a) Mean, b) LSD $_{5 \%}$. Note: Shoots and roots in the 4-6-leaf stage, leaves at the beginning of flowering.

Table 5. Effect of $\mathrm{Cu}$ fertilization on the yield components of maize and the $\mathrm{Cu}$ content of plant organs (chernozem loam soil with lime deposits, Nagyhörcsök, Mezőföld). (1) $\mathrm{Cu}$ rates, $\mathrm{kg} \cdot \mathrm{ha}^{-1}$. (2) Yield components at harvest. (3) $\mathrm{Cu}$ content, $\mathrm{mg} \cdot \mathrm{kg}^{-1}$. (4) Kernels. (5) Shoots. (6) Roots. (7) Leaves. (8) Stalks. a) Mean, b) LSD $5 \%$. Note: Mean 1000-kernel weight: $278 \mathrm{~g}$.

Table 6. Mean composition of maize in 1991 (chernozem loam soil with lime deposits, Nagyhörcsök, Mezőföld). (1) Element symbol. (2) Units. (3) Shoots. (4) Roots. (5) Leaves. (6) Stalks. (7) Kernels. (8) In the 4-6-leaf stage. (9) At flowering. (10) At harvest.

Table 7. Mean element uptake of maize at harvest in 1991 (chernozem loam soil with lime deposits, Nagyhörcsök, Mezöföld). (1) Element symbol. (2) Units. (3) Stalks. (4) Kernels. (5) Together. (6) Specific content. Note: Element content of $1 \mathrm{t}$ grain + the corresponding by-products. 